\title{
GROWTH AND FLOWERING OF 'PUYAT' DURIAN (Durio zibethinus Murr.) AS INFLUENCED BY DIFFERENT TYPES OF FERTILIZER APPLICATION
}

\author{
Alminda Magbalot-Fernandez ${ }^{1}$, Kharelle Samantha Ablen ${ }^{2}$ and Saikat Basu ${ }^{3}$ \\ ${ }^{1}$ Rizal Memorial Colleges Inc. Davao City \\ ${ }^{2}$ University of Southeastern Philippines, Tagum-Mabini Campus \\ ${ }^{3}$ PS Lethbridge, AB Canada T1J 4B3
}

\begin{abstract}
This study was conducted to evaluate the effect of different types of fertilizer application on the growth and flowering of 'Puyat Durian' (Durio Zibethenus Murr.); and determine the best fertilizer application for the optimum production of Durian. Ten (10) year old trees at Canoy Durian Farm, Pindasan, Mabini, Compostela Valley Province were tested from November 2015 to March 2016.

The experiment was laid out in Randomized Completely Block Design (RCBD) with six treatments, replicated three times. The treatments were: T1- Untreated; T2-Recommended Rate- RR (based on soil analysis); T3- Optimum Rate- OR + (3kg NPK+1kg MOP); T4- OR+ GOFF; T5- RR+ GOFF; T6- GOFF (Green-shield Organic-based Fortified Foliar Fertilizer).Statistical analysis showed that there were significant differences among treatments in terms of trees with flushes and number of flowers per cluster but no significant effects were observed in canopy diameter and number of flower cluster per tree.

Result of the study showed that fertilizer application increased the number of flower per cluster of 'Puyat' Durian and enhanced flushing of durian trees. The study further revealed that organic based foliar fertilizer alone enhanced flowering up to five times higher than without application (control). While numerically, GOFF (Green-shield Organic-based Fortified Foliar Fertilizer) alone had the highest number of flower cluster per tree.
\end{abstract}

Keywords: Growth, Flowering, 'Puyat', Durian, Foliar, Fertilization, Durio zibethinus Murr.

\section{INTRODUCTION}

Durian (Durio zibethinus Murr.) is a native of Southeast Asia originating specifically from Borneo. It is popularly known as the 'King of Tropical Fruits' with a strong and pungent flavour when ripe. It is one of the most expensive fruits in the ASEAN region because of its unique taste and nutritional value. It is high in carbohydrates, calcium, phosphorous and ascorbic acid. It is eaten fresh as dessert, processed into candies, preserves and jams, pureed into fillings for rolls, tarts and pies, or used as flavouring for ice cream. Among the major fruits grown in the country, durian ranked 7th in terms of area planted and 8th in terms of volume of production in year 2000. Banana remained to be on top followed by mango and pineapple (Bureau of Agricultural Statistics, 2002).In the Philippines, durian trees are grown as a monocrop or intercropped with coconut and other fruits trees (Bareja 2012).

The demand for durian fruit is increasing rapidly in the ASEAN region and in other countries. Thailand and Malaysia are the main producers. Taiwan, Hong Kong and Singapore are major importers of durian accounting for

*Corresponding author: almindafernandez5@gmail.com 
90\% of the total exports from Malaysia, Thailand and Indonesia.Durian is being produced mainly in Mindanao and to some extent in Western and Eastern Visayas and Southern Tagalog. Southern Mindanao recorded the highest production area at an increasing rate ranging from 2,005 ha in 1992 to 5,091 ha in 2001. The area planted in ARMM has not changed remarkably but in CARAGA area ranged from 439 ha to 1,619 ha while Central Mindanao covered 119 ha in 1992 and reached to 1,430 ha in 2001.However, it was observed that production volume in ARMM shows a decreasing trend having 19,326 in 1992 reaching a peak of 20,804 $\mathrm{t}$ in 1997 and decreased to 14,779 $\mathrm{t}$ in 2001. The production in Southern Mindanao fluctuates ranging from 6,786 t to 9,049 $\mathrm{t}$, which is much lower than in ARMM despite larger hectare covered (PCARRD, 2000).

The other Asian countries producing durian such as Malaysia has been producing to as much as 400,000 t while Indonesia had 200,000 t. The Philippine durian production markedly lagged behind, but the country is trying to enhance its potential to increase production. At the moment the country has not been into export and there exist a very low per capita consumption. However, if the Philippines can increase the production of good quality fruits rapidly, it can compete with other exporting countries (Bureau of Agricultural Statistics, 2002).

Hence, to increase domestic production of durian, an efficient fertilization program should be developed to optimize production and cater both local and export demands.Various fertilization techniques and foliar supplements have been done to maximize the growth and establishment of various crops (Magbalot-Fernandez and De Guzman 2021, 2019; Magbalot-Fernandez et al. 2020; Magbalot-Fernandez and Montifalcon 2019; Montifalcon and Fernandez 2017; Fernandez and Andigan 2017; Fernandez and Sabay 2016; Fernandez and Caballes 2016; Fernandez and Quilab-Tud 2016; Fernandez and Miñoza 2015; Fernandez and Lumbo 2015; Fernandez and Tipay 2013; Fernandez and De Guzman 2013; Loquias et al. 1997).

This study was conducted to know the effects of different types of fertilizer application on the growth and flowering of 'puyat' durian and determine the best fertilizer application for the optimum growth and flowering of durian.

\section{MATERIALS AND METHODS}

The study was conducted at Canoy Durian Farm, Purok 4, Pindasan, Mabini, Compostela Valley Province from December 2016 to March 2016.Ten (10) years old 'Puyat' durian trees were used in the study.
One kilogram of soil sample were collected at random at the area. It was sieved and air-dried and sent to Soil Laboratory for analysis. The experiment was laid-out in Randomized Complete Block Design (RCBD) with six treatments, replicated three times with one sample per treatment per replication.

The treatments were:T1-Control (No Application); T2RR-Recommended Rate (based on soil analysis); T3OR- Optimum Rate (3 kg NPK + 1 kg MOP); T4-OR + GOFF; T5- RR + GOFF; and T6-GOFF (Green-shield Organic-based Fortified Foliar Fertilizer) only.

Ring weeding was done manually whenever necessary. Rainfall was the source of water supply. Irrigation was done when $30 \mathrm{~cm}$ depth of the soil was dry. Application of recommended rate fertilizers based on soil analysis such as $0.93 \mathrm{~kg}$ of Ammonium sulphate (21-0-0), $2.3 \mathrm{~kg}$ of Muriate of Potash (0-0-60), $0.37 \mathrm{~kg}$ of Urea (46-0-0), $2 \mathrm{~kg}$ of Ammonium phosphate (16-20-0) and $6 \mathrm{~kg}$ of Complete fertilizer (14-14-14) as well as Optimum Rate based on PCARRD Durian Technical Committee (2000) (3 kg NPK $+1 \mathrm{~kg}$ MOP) was done using poke hole method. The Greenshield Organic-based Fortified Foliar Fertilizer was applied at the rate of $100 \mathrm{ml} / \mathrm{L}$ every 10 days interval. Pest and diseases were controlled using insecticides and fungicides.

\section{Data Gathered}

The average diameter of canopy was measured in meter having one sample tree per treatment per replication from the base of the tree up to the canopy using meter stick.The numbers of flowers per cluster and flower clusters, per tree were counted during flowering up to the duration of the study. Four sample clusters at north, south, east and west points were taken. The trees with flushing were noted at 30 to 60 days after fertilizer application. The data were analyzed using the Analysis of Variance (ANOVA) in Randomized Complete Block Design (RCBD) and the differences among treatment means were compared using the Tukey's Honest Significant Differences.

\section{RESULTS AND DISCUSSION}

\section{Canopy Diameter Increment (m)}

The canopy diameter increment $(\mathrm{m})$ of durian was not significantly affected by different types of fertilizer application as shown in Table 1 . Hence, both basal and foliar fertilizer application has no influence on the growth of canopy of durian. The canopy diameter increase ranged from $3 \mathrm{~m}$ to $4 \mathrm{~m}$ after 60 days. 
Table 1: Canopy Diameter Increment (m) of 'Puyat' Durian as influenced by different types of fertilizer application.

\begin{tabular}{|l|l|l|}
\hline TREATMENTS & Initial & $\begin{array}{l}\text { Canopy Diameter at Increment 60 } \\
\text { Days }{ }^{\text {nffter Application }}\end{array}$ \\
\hline $\mathrm{T}_{1}$ (Control) & 3.08 & 0.04 \\
\hline $\mathrm{T}_{2}$-Recommended Rate (RR) & 3.30 & 0.48 \\
\hline $\mathrm{T}_{3}$ - Optimum Rate (OR) & 2.56 & 0.34 \\
\hline $\mathrm{T}_{4}$ - OR + GOFF) & 3.21 & 0.57 \\
\hline $\mathrm{T}_{5}-\mathrm{RR}+$ GOFF & 3.38 & 0.34 \\
\hline $\mathrm{T}_{6}$ - GOFF (Green-shield & 3.15 & 0.18 \\
\hline Organic-based & Fortified Foliar & Fertilizer \\
\hline
\end{tabular}

$\mathrm{CV}=73.99 \%$

${ }^{\mathrm{ns}}=$ not significant

\section{Trees with Flushes}

The trees with flushes in 'Puyat' Durian at 30 days after application and 60 days after application were significantly affected by different types of fertilizer application (Table 2).It was noted that the only fertilized trees have flushes at 30 DAA and 60 DAA. This observation also revealed that GOFF Green-shield Organic-based Fortified Foliar Fertilizer alone enhanced the flushing of 'Puyat' durian trees.
Cultural techniques such as pruning, fertilization, irrigation, and crop protection at an appropriate time, will stimulate leaf flushing and help new leaves to grow in a healthy manner (www.hawaiitropicalfruitgrowers.org, Retrieved February 2016).To ensure a steady supply of micronutrients, it is desirable to incorporate the application of organic fertilizers with the fertilization program (Bareja, 2012).

Table 2: Trees with Flushes in 'Puyat' Durian as affected by different types of fertilizer.

\begin{tabular}{|l|l|l|}
\hline TREATMENTS & \multicolumn{2}{|c|}{ Trees with flushing } \\
\hline & $30 \mathrm{DAA}^{*}$ & $60 \mathrm{DAA}^{*}$ \\
\hline $\mathrm{T}_{1}$ (Control) & $0.00 \mathrm{~b}$ & $0.33 \mathrm{~b}$ \\
\hline $\mathrm{T}_{2}$ (Recommended Rate- RR) & $1^{\mathrm{a}}$ & $1^{\mathrm{a}}$ \\
\hline $\mathrm{T}_{3}($ Optimum Recommendation- OR) & $1^{\mathrm{a}}$ & $1^{\mathrm{a}}$ \\
\hline $\mathrm{T}_{4}(\mathrm{OR}+$ GOFF $)$ & $1^{\mathrm{a}}$ & $1^{\mathrm{a}}$ \\
\hline $\mathrm{T}_{5}(\mathrm{RR}+$ GOFF) & $1^{\mathrm{a}}$ & $1^{\mathrm{a}}$ \\
\hline $\begin{array}{l}\mathrm{T}_{6} \text { GOFF (Green-shield } \\
\text { Organic-based Fortified Foliar Fertilizer })\end{array}$ & $1^{\mathrm{a}}$ & $1^{\mathrm{a}}$ \\
\hline
\end{tabular}

$\mathrm{CV}=26.51 \%$

*= significant

Means in column with the same letter are not significantly different at 5\% level using HSD.

\section{Number of Flowers}

Table 3 and Figure 1 present the number of flower clusters per tree and the number of flowers per cluster. Significant differences were observed in terms of number of flowers per cluster but not significant effect in the number of cluster per tree.

Result showed that the fertilizer application increased the number of flower per cluster of 'Puyat' Durian. The study further revealed that GOFF (Green-shield Organic-based Fortified Foliar Fertilizer) alone enhanced flowering up to five times higher than without application (control). While numerically, Green-shield Organic-based Fortified Foliar Fertilizer alone also had the highest number of flower cluster per tree. 
Aldrich and Leng (1965) reported that foliar fertilizer have great effects into the plant and will ensure plant growth and development.Brady (1974) mentioned three methods of applying liquid fertilizer as direct soil application, through irrigation by water, and foliar spray. Foliar spray is the most effective method for micronutrient fertilizer application because it checks particular nutrient deficiency symptoms.

Moreover, Lee (2008) stated that foliar fertilizer applied to the leaves is the most efficient way to get food nutrients for your crop for it produces maximum yield and quality. Plants generally take in nutrients more efficiently through foliar feeding than through root uptake. Foliar fertilizer is mixed significantly for foliar feeding, optimizing nutrient uptake through the stomata in the leaves. Foliar feeding is a method for correcting soil deficiencies and overcoming the soils inability to transfer nutrients to the plant. Test have shown that foliar feeding is 8-10 times more effective than soil feeding and up to $90 \%$ of a foliar feed solution can be found in the smallest root of the plant within 60 minutes application.

The application of a foliar fertilizer with a proper nutrient formula, in addition to soil fertilization, gives the best results. Growers should spray 4-6 times at intervals of one week after blooming, in order to increase the size and quality of fruit (Chau 1997). Foliar application should be considered only a supplement to supply nutrients during peak periods of demand when an immediate response is needed (durianinfo.blogspot.com). Durian (local cultivar) trees applied with $5 \mathrm{~kg}$ complete fertilizer (14-14-14) per tree and supplemented with foliar fertilizer (20-5-30) significantly produced more fruits (158 fruits per tree) compared with those applied with complete fertilizer alone (41 fruits per tree) as reported by Loquias et al. (1997).

Various studies also confirmed the benefits of basal and foliar fertilization on other crops (Magbalot-Fernandez and De Guzman 2021, 2019; Magbalot-Fernandez et al. 2020; Magbalot-Fernandez and Montifalcon 2019; Montifalcon and Fernandez 2017; Fernandez and Andigan 2017; Fernandez and Sabay 2016; Fernandez and Caballes 2016; Fernandez and Quilab-Tud 2016; Fernandez and Miñoza 2015; Fernandez and Lumbo 2015; Fernandez and Tipay 2013; Fernandez and De Guzman 2013; Loquias et al. 1997).

Table 3: Number of Flowers of 'Puyat' Durian as affected by different types of fertilizer application.

\begin{tabular}{l|c|c|}
\hline TREATMENTS & No. of Flower Cluster/Tree ns & No. of Flowers/ Cluster $* *$ \\
\hline $\mathrm{T}_{1}$ (Control) & 3.00 & $5.75 \mathrm{~b}$ \\
\hline $\mathrm{T}_{2}$ (Recommended Rate- RR) & 13.33 & $21.58 \mathrm{a}$ \\
\hline $\mathrm{T}_{3}$ (Optimum Rate- OR) & 23.33 & $17.83 \mathrm{ab}$ \\
\hline $\mathrm{T}_{4}$ (OR + GOFF) & 37.67 & $20.66 \mathrm{a}$ \\
\hline $\mathrm{T}_{5}$ (RR + GOFF) & 21.33 & $17.66 \mathrm{ab}$ \\
\hline $\begin{array}{l}\mathrm{T}_{6} \text { GOFF (Green-shield Organic-based } \\
\text { Fortified Foliar Fertilizer) }\end{array}$ & 67.00 & $29.41 \mathrm{a}$ \\
\hline $\begin{array}{l}\mathrm{CV}= \\
\mathrm{ns}=\text { not significant } \\
* *=\text { highly significant } \\
\text { Means in column with the same letter superscript are not significantly different at 1 \% level using HSD }\end{array}$
\end{tabular}

\section{CONCLUSION}

Result of the study showed that the fertilizer application increased the number of flower per cluster of 'Puyat' Durian. It also enhanced flushing of durian trees. The study further revealed that organic based foliar fertilizer alone enhanced flowering up to five times higher than without application (control). While numerically, GOFF (Greenshield Organic-based Fortified Foliar Fertilizer) alone had the highest number of flower cluster per tree.
Hence, organic based foliar fertilizer and basal fertilization are effective for flowering of durian as it increased the number of flowers per cluster and enhanced flushing of trees.Based on the result of the study, the application of Green-shield Organic-based Fortified Foliar Fertilizer alone is recommended for optimum flowering of 'Puyat' durian. Further study is also recommended to test its efficacy on the fruit yield of 'Puyat' Durian. 

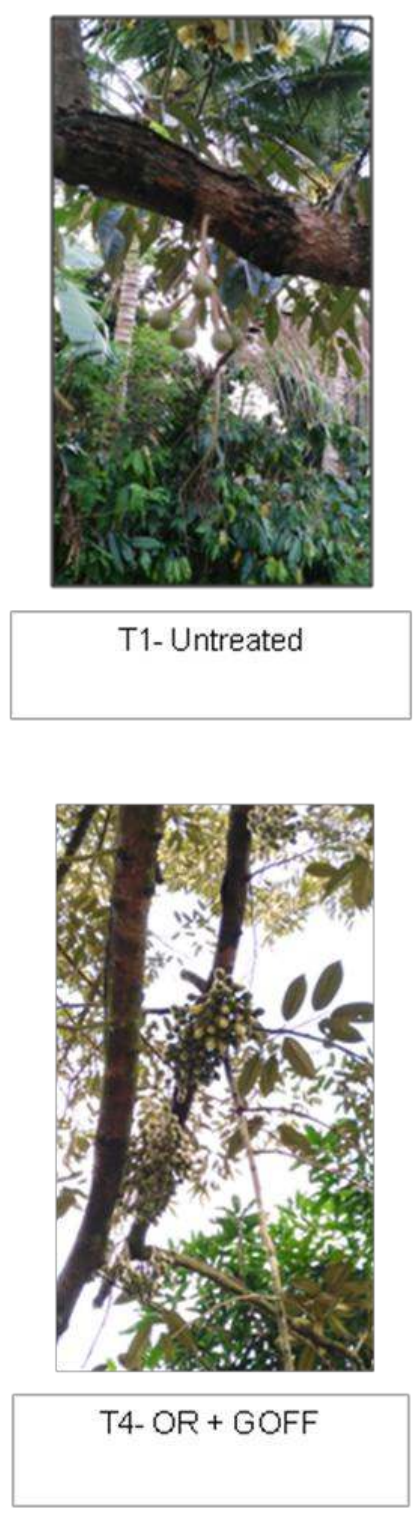
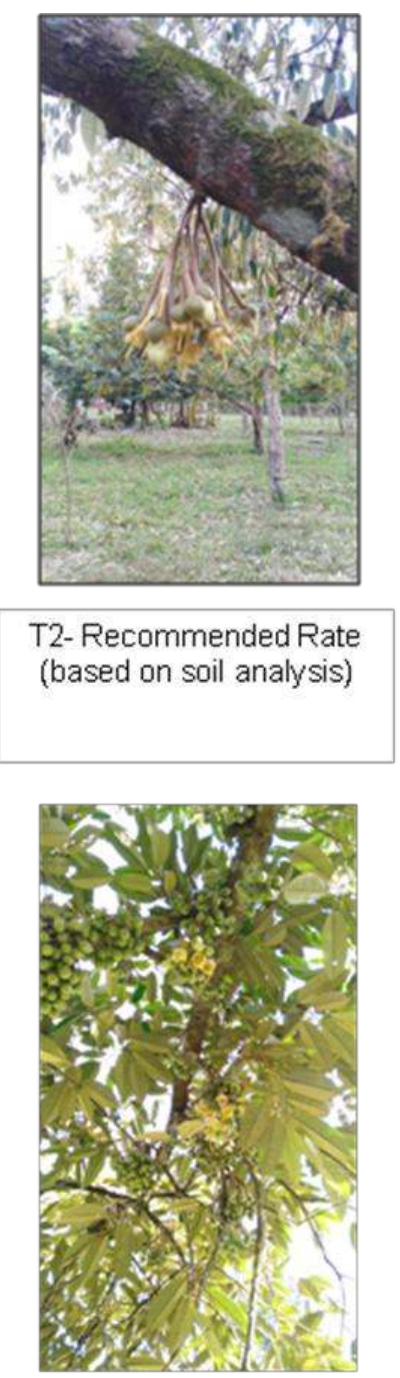

T5- RR + GOFF

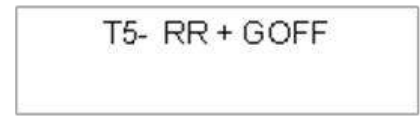

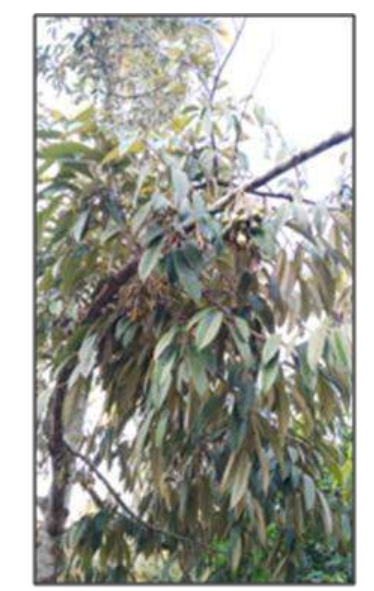

T3- Optimum

Recommendation $(3 \mathrm{~kg}$ $\mathrm{NPK}+1 \mathrm{kl}$. MOP)

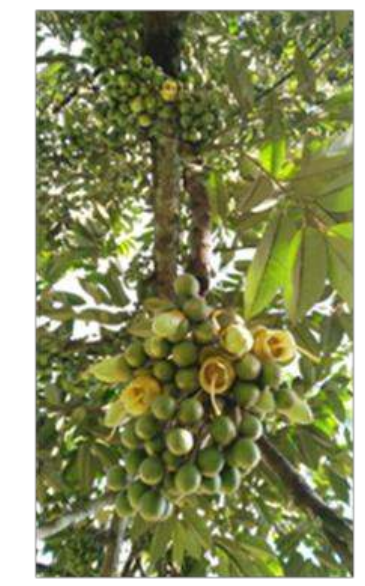

T6- GOFF (Green-shield Organic-based Fortified Foliar Fertilizer

Figure 1: Flowering of 'Puyat' Durian trees as affected by different fertilization at Canoy Durian Farm on March 2016.

\section{REFERENCES}

1. ALDRICHSR and LENGER. 1965. Modern Crop Production. The Farm Quality Concentration. Ohio, USA. Pp.300.

2. Bareja BG. 2012. Durian tree, that crop with the fruit that "smells like hell but tastes like heaven". Retrieved from https://www.cropsreview.com/durian-tree.html on 03 Nov 2018.

3. Brady NC. 1974. The Nature and Properties of Soil. Mc Millan Publishing Co., Inc.New York, Toronto, London. The Interstate Printers. p35.

4. Bureau of Agricultural Statistics (BAS). 2002. Crop Production Statistics.
5. Chau NM. 1997. Using Fertilizer for Some FruitTrees. Agriculture, Land Resources and Fertilizer Use in Vietnam. Youth Publisher, Ho Chi Minh City, Vietnam.

6. Fernandez AM and Andigan AM. 2017. Stimulate Hormones for Higher Yield of Pechay (Brassica pekinensis). Lambert Academic Publishing. Saarbrucken, Germany. ISBN 978-3-330-05054-9. https://www.lap-publishing.com/catalog/details //store/gb/book/978-3-330-05054-9/stimulatehormones-for-higher-yield-of-pechay-brassicapekinensis.

7. Fernandez AM and Caballes J. 2016. Stimulants for tissue-cultured 'Lakatan'banana (M. paradisiaca) 
plantlets. Fastpencil publication, USA. http//fp.fastpencil.com ISBN 978-1-49-990174-0. https://www.amazon.com/STIMULANTS-TISSUEC U L T U R E D - L A K AT A N - p a r a d i s i a c a PLANTLET/dp/1976243882.

8. Fernandez AM and De Guzman CC. 2013.Quality and Nutrition of Pummelo as Influenced by Potassium. Journal of Environmental Science and Engineering2(2A):97-105, ISSN 2162-5298, David Publishing Co., USA. DOI:10.17265/21625298/2013.02.004, http://www.davidpublisher.org/ Public/uploads/Contribute/5518fc160f42b.pdf.

9. Fernandez AM and Lumbo, KC. 2015. Enhanced Growth Of Tissue-Cultured Abaca Hybrid (Musa textilis Var. 'Seven') Using Stimulate Hormones. CreateSpace Independent Publishing Platform. ISBN10: 1976304520, ISBN-13: 978-1976304521. https://www.amazon.com/ENHANCED-TISSUEC U L T U R E D - t e x t i l i s - S T I M U L A T E HORMONES/dp/1976304520.

10. FernandezAM and Miñoza E. 2015. Growth and Yield of Pechay (Brassica pekinensis) as affected by Green Herds Organic Based Foliar Fertilizer. Special Issue: First International Conference on Quality Management of Organic Horticultural Produce 2015. Book of Proceedings, Horticulturae. Basel, Switzerland. IS SN 2311-7524. p. 346. https://www.researchgate.net/publication/337549018 _Growth_and_Yield_of_Pechay_Brassica_pekinensi s_as_affected_by_Green_Herds_Organic_Based_Fo liar_Fertilizer.

11. Fernandez AM and Quilab-Tud AF. 2016. Optimum Growth In Tissue-Cultured 'Cardava' (Musa balbisiana) Banana Plantlets Using Stimulate. CreateSpace Independent Publishing Platform. ISBN-10: 1549738518, ISBN-13: 978-1549738517. https://www.amazon.com/OPTIMUM-TISSUEC U L T URE D - b a lb i s i an a - P L A N T LE T S STIMULATE/dp/1549738518.

12. Fernandez AM and Sabay JL. 2016. Growth of tissue-cultured abaca hybrid (Musa textiles var. 'seven') plantlets using bioforge supplement. Imperial Journal of Interdisciplinary Research. Vol. 2, Issue 8. ISSN 2454-1362, http://www.onlinejournal.in/ IJIRV2I8/040.pdf.

13. Fernandez AM and Tipay WC. 2013. Fermented Banana Peel as Potassium Foliar Fertilizer in Pummelo. Southeastern Philippines Journal of Research and Development 22(2):27-39, ISSN 01176293, Research Division, University of Southeastern Philippines, Obrero, Dava City. https://www.researchgate.net/publication/337548703 _Fermented_Banana_Peel_as_Potassium_Foliar_Fer tilizer_in_Pummelo.
14. http://durianinfo.blogspot.com/p/the-origin-ofdurian.html. Retrieved September142015.

15. Lee PJ. 2008.http://www.planetnatural.hm/ site/xelpy/sac/organic\%fertilizers/foliar\%2020 zer.

16. Loquias VL, Pascual OC \& Cantila MS. 1997. Supplemental Foliar Fertilizer for Durian. https://agris.fao.org/agris-search/search.do? recordID=PH1998100554

17. Magbalot-FernandezAand De Guzman C. 2021. Physico-Chemical Quality and Sensory Evaluation of Pummelo Fruit as Influenced by Potassium Fertilization. Annals of Tropical Research 43 (1):120https://annalsoftropicalresearch.com/wpcontent/uploads/pdf_files/Volume43No.1/9.pdf.

18. Magbalot-Fernandez Aand De Guzman C. 2019. Phenology of 'Magallanes' Pummelo (Citrus maxima) Trees and Its Growth and Development as Influenced by Potassium Nutrition. Asian Journal of Research in Agriculture and Forestry, 3(4), 1-18. https://doi.org/ 10.9734/ajraf/2019/v3i430043

19. Magbalot-Fernandez A and De Guzman C. 2019. Potassium Fertilization for Higher Flowering and Fruit Yield in 'Magallanes' Pummelo (Citrus maxima). Asian Journal of Agricultural and Horticultural Research, 3(4), 1-8. IS SN: 2581-4478. https://doi.org/10.9734/ajahr/2019/v3i430004.

20. Magbalot-Fernandez A, Matuguinas J.P. \& Basu SK. 2020. Growth Performance of Tissue-Cultured 'Lakatan' Banana (Musa acuminata) Plantlets Using Stimulant. International Journal on Agricultural Sciences 12(2):56-68 ISSN No.: 0976-450X.

21. Magbalot-Fernandez A and Montifalcon L. 2019. Effects of Organic-based Fortified Foliar Fertilizer on the Growth and Yield of 'Lakatan' Banana (Musa acuminata). Asian Journal of Research in Crop Science, 3(4), 1-9. IS SN: 2581-7167. https://doi.org/10.9734/ajrcs/2019/v3i430053.

22. Montifalcon JR and Fernandez AM. 2017 Enhanced Growth and Yield of Lowland Rice (Oryza sativa L.) with Greenshield Organic-based Fortified Foliar Fertilizer. Asian Journal of Soil Science and Plant Nutrition 1(1): 1-10, 2017; Article no. AJSSPN.33267. http://www.journalajsspn.com/ index.php/AJSSPN/article/view/97.

23. PCARRD Durian Technical Committee. 2000. The Philippine recommends for durian. Los Baños, Laguna: PCARRD. 111P. (Philippines Recommends Series No. 87).

24. www.hawaiitropicalfruitgrowers.org. Retrieved February 10, 2016. 